\title{
Pengaruh Model Discovery Learning Terhadap Keterampilan Proses Sains Dalam Pelajaran IPA Materi Sifat dan Perubahan Wujud Benda di SDN 1 Tanjunganom
}

\author{
Dena Hafifah, Dea Asri Pujiasti, Widdy Sukma Nugraha
}

Institut Pendidikan Indonesia

denahafifah97@gmail.com

\section{Article History}

accepted 2/11/2019

approved 23/11/2019

published 31/12/2019

\begin{abstract}
The problem in this research is the science process skills consisting of seven indicators observing, classifying, measuring, predicting, using tools and materials or conducting simple experiments, communicating, and concluding. This study aims to determine the effect of discovery learning models on the fifth grade science process skills in natural science subjects at SDN 1 Tanjunganom. The results showed that the discovery learning model had a significant effect on the science process skills of the fifth grade students of SDN 1 Tanjunganom on the subject of the nature and change of matter. This is based on the results of the calculation of the data obtained posttest tcount of 6.100 is greater than ttable of 2.021 and for the results of post observation tcount of 4.529 is greater than ttable of 2.021 then $\mathrm{Ha}$ is accepted. So it can be concluded that the application of discovery learning models can affect science process skills in natural science subjects at SDN 1 Tanjunganom.
\end{abstract}

Keywords: Discovery Learning, Science Process Skills, Student

\begin{abstract}
Abstrak
Permasalahan dalam penelitian ini yaitu keterampilan proses sains yang terdiri dari tujuh indikator mengobservasi, mengklasifikasikan, mengukur, memprediksi, menggunakan alat dan bahan atau melakukan percobaan sederhana, mengomunikasikan, dan menyimpulkan. Penelitian ini bertujuan untuk mengetahui pengaruh model pembelajaran discovery learning terhadap keterampilan proses sains kelas V pada mata pelajaran IPA di SDN 1 Tanjunganom. Hasil penelitian menunjukkan model discovery learning berpengaruh signifikan terhadap keterampilan proses sains siswa kelas V SDN 1 Tanjunganom pada pokok pembahasan sifat dan perubahan wujud benda. Hal ini didasarkan pada hasil perhitungan data diperoleh hasil posttest thitung sebesar 6,100 lebih besar dari ttabel yang sebesar 2,021 dan untuk hasil post observasi thitung sebesar 4,529 lebih besar dari ttabel yang sebesar 2,021 maka Ha diterima. Sehingga dapat disimpulkan bahwa penerapan model discovery learning dapat mempengaruhi keterampilan proses sains pada mata pelajaran IPA di SDN 1 Tanjunganom.
\end{abstract}

Kata kunci: Discovery Learning, Keterampilan Proses Sains, Siswa

Social, Humanities, and Education Studies (SHEs): Conference Series https://jurnal.uns.ac.id/shes

p-ISSN 2620-9284

e-ISSN 2620-9292 


\section{PENDAHULUAN}

IImu pengetahuan alam merupakan terjemahan kata-kata dalam bahasa inggris yaitu natural science, natural berhubungan dengan alam atau bersangkut paut dengan alam, science artinya ilmu pengetahuan. Jadi ilmu pengetahuan alam (IPA) atau science pengertiannya dapat disebut sebagai ilmu tentang alam. Ilmu yang mempelajari peristiwa-peristiwa yang terjadi di alam ini. (Samatowa, 2016, hlm. 3)

Sebuah organisasi dalam naungan Organization Economic Cooperation and Development (OECD) yang bernama Program for International Student Assesment (PISA) merupakan survei pendidikan yang diadakan dalam selang waktu tiga tahun sekali mengenai sistem pendidikan dan kemampuan siswa. Pada PISA tahun 2012, Indonesia menempati peringkat 64 dari 65 negara dengan hasil skor literasi IPA sebesar 382 (OECD, 2013, hlm 5). Sementara pada hasil PISA tahun 2015, Indonesia menempati peringkat ke 62 dari 70 negara dengan skor literasi IPA sebesar 403 (OECD, 2016, hlm 5).

Berdasarkan penilaian dari survei Trends in Mathematics and Science Study (TIMSS) oleh The International Association for the Evaluation of Educational for Achievment (IEA) Tahun 2015 posisi Indonesia menempati peringkat ke 44 dari 47 negara dengan nilai rata-rata 397 (IEA, 2016). Kemampuan sains peserta didik Indonesia dibawah nilai rata-rata 500 dan hanya mencapai Low International Benchmark. Hasil interpretasi survei TIMSS terhadap kemampuan siswa Indonesia baik ditinjau dari aspek kognitif (knowing, applying, reasoning), kemampuan siswa Indonesia rata-rata masih berada pada kemampuan knowing (Efendi, 2010). Dengan capaian tersebut, skor rata-rata sains siswa Indonesia hanya mampu mengenali sejumlah fakta dasar tetapi belum mampu mengkomunikasikan dan mengaitkan berbagai topik sains, apalagi menerapkan konsep-konsep yang kompleks dan abstrak. Berdasarkan paparan tersebut, mengindikasikan keterampilan proses sains masih rendah.

Salah satu faktor penyebab rendahnya skor keterampilan proses sains siswa terletak pada proses pembelajaran sains (IPA) di sekolah. Mata pelajaran IPA merupakan salah satu mata pelajaran eksak yang diberikan pada siswa dari sekolah dasar sampai sekolah menengah atas. Pelajaran IPA dianggap sebagai pelajaran yang sulit dan membosankan bagi siswa, karena guru dalam mengelola pembelajaran masih bersifat konvensional. Transfer pengetahuan sains (IPA) siswa diperoleh melalui penjelasan atau ceramah mengenai konsep yang bersifat abstrak sehingga mengakibatkan siswa tidak memahami pembelajaran. Pembelajaran yang dilakukan melalui pengamatan objek secara langsung (alam sekitar) dapat menumbuhkan kemampuan dan pengalaman belajar dan membentuk pengetahuan siswa. (Feni, 2014, hlm. 13).

Berdasarkan pendapat Piaget (dalam Santrock, 2012) tahap perkembangan kognitif dan moral pada anak sekolah dasar, anak-anak belajar melalui permainan di lapangan bermain dengan berinteraksi bersama rekan sebayanya. Maka dalam pembelajaran IPA menggunakan metode atau model pembelajaran yang sesuai dengan perkembangan kognitif siswa agar dapat menyampaikan materi pelajaran secara tepat.

Menurut Hamalik (dalam Susanto, 2013, hlm. 3), belajar adalah memodifikasi atau memperteguh perilaku melalui pengalaman (learning is defind as the modificator or strengthening of behavior through experiencing). Menurut pengertian ini, belajar merupakan suatu proses, suatu kegiatan, dan bukan merupakan suatu hasil atau tujuan. Dengan demikian, belajar itu bukan sekadar mengingat atau menghafal saja, namun lebih luas dari itu yaitu mengalami.

Berdasar hasil penelitian di atas, jika ditinjau dari sudut pandang mikro yaitu tingkat satuan pendidikan yang dalam hal ini tingkat sekolah dasar, khususnya di SDN 
I Tanjunganom berdasarkan hasil observasi kelas $V$ di SDN I Tanjunganom menunjukkan hal yang sama, hal itu ditandai dengan proses pembelalajaran yang monoton atau metode pembelajaran yang menggunakan ceramah dan penugasan dan hanya menjadikan siswa sebagai objek pembelajaran, sehingga siswa belum mendapat pengalaman belajar yang menantang dan bermakna.

Berdasarkan fakta-fakta yang telah diungkapkan, maka dipandang perlu untuk menerapkan suatu model pembelajaran yang memberikan stimulus peserta didik untuk meningkatkan keterampilan proses sains.

Salah satu upaya untuk mewujudkan pembelajaran yang tidak membosankan bagi siswa dan meningkatkan kualitas proses belajar mengajar IPA adalah dengan menggunakan model pembelajaran yang sesuai dengan tujuan pembelajaran IPA. Dengan model pembelajaran yang melibatkan siswa secara aktif. Mengembangkan model pembelajaran yang kreatif dan inovatif sangat berkaitan dengan realitas kehidupan, bagaimana para siswa mampu diajak dan diberi motivasi untuk berpikir inovatif dalam menemukan sesuatu yang baru. Model pembelajaran ini mampu merangsang siswa dalam menganalisis suatu persoalan yang sedang terjadi di sekolah maupun di lingkungan masyarakat. Penerapan model pembelaja-ran kreatif dan inovatif yang dimaksud adalah pembelajaran berdasarkan penemuan (discovery learning).

Berdasarkan level inkuiri secara pedagogi pendidikan, level pembelajaran penemuan (discovery learning) ditempatkan sebagai bentuk fundamental dari pembelajaran berorientasi inkuiri. Fokus dari pembelajaran penemuan (discovery learning) adalah tidak pada menemukan aplikasi pengetahuan tetapi lebih pada membangun pengetahuan dari pengalaman. Kurniasih \& Sani (dalam Salmi, 2014, hlm. 68-71).

Dengan penelitian ini diharapkan para guru dapat lebih selektif memilih model mengajar yang tepat dan dapat mudah dicerana oleh siswa. Berdasarkan latar belakang diatas untuk mengetahui pengaruh model discovery learning terhadap keterampilan proses sains di kelas V SD khususnya mata pelajaran IImu Pengetahuan Alam, maka dilaksanakan Penelitian dengan judul Pengaruh model discovery learning terhadap keterampilan proses sains dalam pelajaran IPA materi sifat dan perubahan wujud benda kelas V SDN I Tanjungaom Samarang.Definisi Model Pembelajaran Discovery Learning.

Secara umum penelitian ini bertujuan untuk menganalisis penerapan dari discovery learning dan pengaruhnya terhadap minat dan hasil belajar siswa. Penelitian ini memiliki tujuan sebagai berikut :

1. Untuk mengetahui keterampilan proses sains kelas $V$ di SDN I Tanjunganom dari penggunaan model discovery learning pada mata pelajaran IPA materi sifat dan perubahan wujud benda

2. Untuk mengetahui penggunaan model pembelajaran discovery learning di kelas $V$ di SDN I Tanjunganom pada mata pelajaran IPA materi sifat dan perubahan wujud benda.

3. Untuk mengetahui ada atau tidak adanya pengaruh model discovery learning terhadap keterampilan proses sains siswa kelas V di SDN I Tanjunganom pada mata pelajaran IPA materi .sifat dan perubahan wujud benda

\section{METODE}

Desain penelitian merupakan langkah- langkah yang perlu diambil jauh sebelum proses penelitian dilakukan agar data yang semestinya diperlukan dapat diperoleh, sehingga akan membawa kepada analisis objektif dan kesimpulan yang berlaku persoalan. Sedangkan desain penelitian yang digunakan untuk penelitian ini adalah Nonequivalent Control Group Design, desain ini hampir sama dengan pretest-posttest 
control group design, hanya pada desain ini kelompok eksperimen maupun kelompok kontrol tidak dipilih secara random (Sugiyono, 2015, hlm. 116).

Penelitian ini dilakukan dengan membandingkan dua kelas, yaitu kelas eksperimen dan kelas kontrol. Sementara itu yang dimaksud kelas eksperimen adalah kelas yang belajar dengan pembelajaran pendekatan discovery learning dan kelas kontrol adalah kelas yang belajar dengan konvensional. Desain penelitian yang digunakan adalah desain yang dikemukakan oleh Sugiyono (2012, hlm. 9) Non Equivalent Group adalah sebagai berikut :

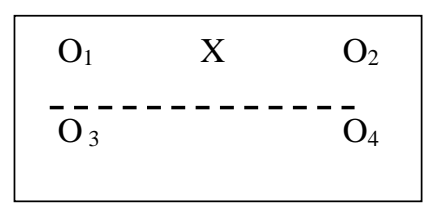

Keterangan:

O1 dan O3 : Keteramilan Proses Sains Siswa siswa sebelum diberi perlakuan.

O2 : Keteramilan Proses Sains Siswa siswa setelah diberi perlakuan.

O4 : Keteramilan Proses Sains Siswa siswa yang tidak diberi perlakuan.

Pengaruh pembelajaran discovery learning terhadap keterampilan proses sains adalah (O2 - O1) - (O4 - O3).

Populasi dalam penelitian ini adalah seluruh siswa SDN I Tanjunganom kelas V. Sampel dalam penelitian ini yaitu kelas $V$ A dan B terdiri dari 30 siswa, kelas A sebagai kelas kontrol mendapat perlakuan menggunakan model konvensional dan B sebagai kelas eksperimen mendapat perlakuan menggunakan model discovey learning.

Teknik pengambilan sampel dalam penelitian ini adalah dengan menggunakan teknik sampling jenuh, yaitu teknik penentuan sampel bila anggota populasi digunakan sebagai sampel (Sugiyono, 2015, hlm. 124). Alasan mengambil teknik sampling jenuh karena menurut Sugiyono (2015) jumlah populasi kurang dari 100 seluruh populasi dijadikan sampel penelitian.

Alat pengumpul data yang bisa dipergunakan dalam melakukan observasi ini adalah dengan menggunakan lembar observasi siswa dan lembar observasi guru:

a. Lembar observasi siswa

Lembar observasi siswa ini berisi aspek keterampilan proses sains yaitu keterampilan mengobservasi, keterampilan mengklasisifikasi, keterampilan mengukur, keterampilan memprediksi/ meramalkan, keterampilan menggunakan alat dan bahan, keterampilan mengkomunikasikan dan keterampilan menyimpulkan disusun berdasarkan indikator-indikator keterampilan proses sains yang telah buat butir pernyatan observasi sebanyak 20 pernyataan.

b. Lembar observasi guru

Lembar observasi guru ini berisi sesuai dengan kesimpulan teori-teori menurut para ahli mengharuskan guru melakukan langkah-langkah dalam model pembelajaran discovery lerning sebagai berikut:

1) memberikan stimulus kepada siswa,

2) mengidentifikasi permasalahan yang relevan dengan bahan pelajaran, merumuskan masalah kemudian menentukan jawaban sementara (hipotesis),

3) membagi siswa menjadi beberapa kelompok untuk melakukan diskusi,

4) memfasilitasi siswa dalam kegiatan pengumpulan data, kemudian mengolahnya untuk membuktikan jawaban sementara (hipotesis), 
5) mengarahkan siswa untuk menarik kesimpulan berdasarkan hasil pengamatannya, dan

6) mengarahkan siswa untuk mengomunikasikan hasil temuannya.

Dari langkah-langkah model discovery learning telah buat butir pernyatan observasi sebanyak 20 pernyataan.

c. Lembar tes

Dalam penelitian ini tes dilakukan dengan pretest dan posttest. Tes dilakukan pada kelas eksperimen dan kelas kontrol. Lembar tes yang akan diberikan terdiri dari 6 soal uraian.

d. Dokumentasi

Menurut Sugyono (2015, hlm. 329) Dokumentasi adalah catatan peristiwa yang sudah berlalu. Dokumentasi bisa berbentuk tulisan, gambar, atau karyakarya monumental seseorang. Digunakan untuk mengetahui dan menggali informasi tentang keterampilan proses sains peserta didik pada perolehan nilai sebagai hasil belajar. Selain itu juga berguna sebagai bukti pelaksanaan tindakan.

\section{A. Keterampilan Proses Sains Awal Siswa}

\section{HASIL DAN PEMBAHASAN}

Kemampuan proses sains awal siswa pada kelas kontrol berdasarkan hasil data pretest mendapatkan persentase keterampilan proses yang termasuk kategori kurang $76 \%$ dan jelek 24\%. Berdasarkan data-data tersebut dapat disimpulkan bahwa keterampilan proses sains siwa kelas kontrol yang paling mendominasi adalah kategori kurang. Sedangkan hasil data pretest kelas eksperimen $87 \%$ kurang dan $13 \%$ jelek. Berdasarkan data-data tersebut dapat disimpulkan bahwa keterampilan proses sains siwa kelas kontrol yang paling mendominasi adalah kategori kurang.

Dan hasil data pre observasi memiliki hasil mean $=30,22 \%$ untuk kelas kontrol, dan mean $=27,08 \%$ untuk kelas eksperimen.

\section{B. Keterampilan Proses Sains Setelah Pembelajaran}

Kemampuan proses sains siswa pada kelas kontrol berdasarkan hasil data posttest pada kelas kontrol mendapatkan persentase keterampilan proses yang termasuk kategori cukup 7\% dan kurang 24\%. Berdasarkan data-data tersebut dapat disimpulkan bahwa keterampilan proses sains siwa yang paling mendominasi adalah kategori kurang. Sedangkan kelas eksperimen 24\% kategori baik sekali, 57\% kategori baik, $19 \%$ kategori cukup.

Dan hasil data post observasi memiliki hasil mean $=59,27 \%$ untuk kelas kontrol, dan mean $=71,87 \%$ untuk kelas eksperimen.

Berdasarkan data-data di atas maka dapat disimpulkan bahwa keterampilan proses siswa pada kelas kontrol yang paling mendominasi adalah kategori kurang. Hal ini dapat diartikan dengan menggunakan model konvensional kurang optimal untuk melatih keterampilan proses sains pada mata pelajaran IPA, dikarenakan model konvensional hanya mendengarkan penjelasan guru sehingga siswa kurang aktif padahal dalam pembelajaran IPA banyak sekali materi yang mengharuskan sebuah percobaan supaya siswa melakukan percobaan/ penemuannya sendiri.

Sedangkan keterampilan proses sains pada kelas eksperimen yang paling mendominasi adalah yang termasuk kategori baik sakali. Hal ini dapat diartikan bahwa dengan menggunakan pembelajaran discovery learning efektif dalam pembelajaran IPA sehingga berpengaruh terhadap keterampilan proses sains siswa. 


\section{Implementasi pembelajaran}

Keberhasilan implemenasi pembelajaran dikelas kontrol yaitu sebesar $90 \%$ sedangkan kelas esksperimen sebesar 99\%. Impleentasi terhadap dua kelas tersebut dalam kategori baik dan menunjukkan bahwa pembelajaran dengan menggunakan model konvensional untuk kelas kontrol dan model discovery learning untuk kelas eksperimen di implementasikan sebaik mungkin sesuai dengan tahapan-tahapan yang telah di tentukan.

\section{Uji Perbedaan Keterampilan Proses Sains Siswa Sebelum Pembelajaran}

Setelah mengetahui bahwa data berdistribusi normal dan homogen dapat di uji perbedaan diketahui bahwa ttabel $=\mathrm{t} 0,05(\mathrm{db}=30+30-2)=\mathrm{t} 0,05(58)=2,0211$, dan ttabel $=\mathrm{t} 0,05(\mathrm{db}=30+30-2)=\mathrm{t} 0,05(58)=2,0211$, karena terdapat dalam tabel $\mathrm{t}$, maka di cari dengan interpolasi t0,05 $(40)=2,0211$ dan t0,05 (60) $=2,0003$. t0,05 (58) $=2,0211-18 / 20(2,0211-2,0003)=2,0023$. Karena -ttabel ttabel yaitu $-2,00230,984$ 2,0023 maka Ho diterima dan dapat disimpulkan bahwa tidak terdapat perbedaan keterampilan proses sains kelas eksperimen dengan siswa kelas kontrol. Dan memiliki hasil mean $=30,22 \%$ untuk kelas kontrol, dan mean $=27,08 \%$ untuk kelas eksperimen.

\section{E. Uji Perbedaan Keterampilan Proses Sains Siswa Setelah Pembelajaran}

Kemudian dilakukan uji homogenitas bahwa harga $p>0,05$ yaitu 0,016>0,05 maka dapat disimpulkan bahwa post observasi keterampilan proses sains antara kelas kontrol dan kelas eksperimen mempunyai variansi yang homogen.

Setelah mengetahui bahwa data berdistribusi normal dan homogen dapat di uji perbedaan diketahui ttabel $=\mathrm{t} 0,05(\mathrm{db}=21+21-2)=\mathrm{t} 0,05(40)=2,021$, karena ttabel ttabel yaitu -2,021 4,529 2,021 maka Ho ditolak dan Ha diterima dan dapat disimpulkan bahwa terdapat perbedaan keterampilan proses sains antara siswa kelas eksperimen dengan siswa kelas kontrol dengan kata lain bahwa model pembelajaran discovery learning berpenngaruh terhadap keterampilan proses sains siswa. Dan memiliki hasil mean $=57,4$ untuk kelas kontrol, dan mean $=80,3$ untuk kelas eksperimen.

\section{F. Uji N-gain}

Data gain ternormalisasi juga menunjukan klasifikasi peningkatan skor siswa yang dibandingkan dengan skor maksimal idealnya. Rataan $\mathrm{N}$-gain menggambarkan peningkatan keterampilan proses sains siswa yang menerapkan pembelajaran dengan model discovery learning maupun yang menerapkan pembelajaran langsung. Dengan hasil rataan n-gain 0,23 katagori rendah untuk kelas kontrol dan 0,63 katagori sedang untuk kelas 0,63.

Hal yang menyebabkan model pembelajaran discovery learnng memiliki raatan dan peingkatan lebih tinggi dibandingkan dengan model konvensional karena model discovery learning dengan cara siswa belajar menemukan sendiri dan aktif didalam pembelajaran.hal ini sesuai dengan teori Wilcox (dalam Hosnan, 2014, hlm. 281-282) menyatakan bahwa dalam pembelajaran dengan penemuan, siswa didorong untuk belajar sebagian besar melalui keterlibatan aktif mereka sendiri dengan konsepkonsep dan prinsip-prinsip dan guru mendorong siswa untuk memiliki pengalaman dan melakukan percobaan yang memungkinkan mereka menemukan prinsipprinsip untuk diri mereka sendiri.

Discovery learning adalah suatu model untuk mengembangkan cara belajar aktif dengan menemukan sendiri, menyelidiki sendiri, maka hasil yang diperoleh akan setia dan tahan lama dalam ingatan. Melalui belajar penemuan, siswa juga bisa belajar berpikir analisis dan mencoba memecahkan sendiri masalah yang dihadapi. 


\section{SIMPULAN}

Berdasarkan hasil penelitian dan pembahasan tentang pengaruh model pembelajaran discovery learning terhadap keterampilan prosese sains siswa materi sifat dan perubahan wujud benda kelas V SDN I Tanjunganom, dapat ditarik kesimpulan sebagai berikut:

1. Keterampilan proses sains awal siswa untuk hasil tes pada kelas kontrol yaitu $45,1 \%$ meningkat menjadi $57,4 \%$ dan kelas eksperimen yaitu $44,1 \%$ meningkat menjadi $80,3 \%$. Dan hasil data keterampilan proses sains awal untuk observasi siswa pada kelas kontrol 30,22\% meningkat menjadi $52,35 \%$ dan kelas eksperimen yaitu $27,08 \%$ meningakat menjadi $65,68 \%$. Ini membuktikan bahwa pada kelas kontrol dan kelas eksperimen mengalami peningkatan akan tetapi peningkatan pada kelas eksperimen lebih signifikan dari pada kelas eksperimen.

2. Penggunaan model discovery learing pada kelas eksperimen yaitu sebesar 99\% termasuk kategori baik membuktikan bahwa model discovery learning dilakkan dengan baik sesuai dengan langkah-langkah yang dilakukan.

3. Pengaruh model pembelajaran discovery learning terhadap keterampilan proses sains materi sifat dan perubahan wujud benda keterampilan proses sains siswa materi sifat dan perubahan wujud benda kelas $\mathrm{V}$ SDN I Tanjunganom, menunjukan keterampilan proses sains siswa meningkat dan mpenggunaan model pembelajaran discovery learning dilakukan dengan baik. Artinya pembelajaran menggunakan model discovery learning mempengaruhi keterampilan proses sains. Keberhasilan implementasi pembelajaran dikelas kontrol yaitu sebesar 99\% termasuk kedalam kategori baik ini menunjukkan bahwa pembelajaran dengan menggunakan model konvensional di implementasikan sebaik mungkin sesuai dengan tahapan-tahapan yang telah di tentukan. Dapat disimpulkan bahwa terdapat peningkatan dari hasil dengan penggunaan model pembelajaran discovery learning di laksanakan sesuai dengan langkah- yang telah di tentukan. Dengan kesimpulan Ho ditolak sehingga Ha diterima. Sehingga hipotesis nol yang menyatakan Tidak ada (tidak terdapat) pengaruh model discovery learning terhadap keterampilan proses sains peserta didik ditolak dan dengan demikian hasil uji-t menyatakan bahwa Ha diterima yaitu ada (terdapat) pengaruh model discovery learning terhadap keterampilan proses sains peserta didik.

\section{DAFTAR PUSTAKA}

Hosnan, M. (2014). Pendekatan Saintifik dan Kontekstual dalam Pembelajaran Abad 21. Bogor: Ghalia Indonesia. Diakses dari https://ettymartha23.wordpress.com/2017/05/08/resesnsi-buku-pendekatansaintifik-dan- kontekstual-dalam-pembelajaran-abad-21/

IEA. (2016). Student Achievement Overview (Science) Grade 4. [online]. Diakses dari : http://timss2015.org/timss-2015/science/student-achievement/

Kemendikbud. (2013). Pembelajaran dengan Pendekatan Scientifik 2013. Diakses dari https://www.kemdikbud.go.id > kemdikbud

Nugraha, A. dkk. (2017). Analisis Kemampuan Berpikir Kritis Ditinjau dari Keterampilan Proses Sains dan Motivasi Belajar melalui Model PBL. Journal of Primary Education.

OECD. (2013). PISA 2012 result : What student know and can do : Students perfomance in reading, mathematics, and science. [online] Diakses dari : www.oecd.org/pisa/key findings/PISA-2012-result-overview.pdf

OECD. (2016). PISA 2015 result in focus. [online]. Diakses dari : www.oecd.ord/pisa/pisa2015-result-in-focus.pdf 
4th National Seminar on Guidance and Counseling (SNBK 2019) and Workshop on

Pedagogical Theory and Practice (WTPP 2019)

SHEs: Conference Series 2 (2) (2019) $163-170$

Oemar, Hamalik, Oemar. (2010). Proses Belajar Mengajar. Jakarta: PT Bumi Aksara.

Salmi, (2014) PENERAPAN MODEL PEMBELAJARAN DISCOVERY LEARNING diakses dari: https://ejournal.unsri.ac.id/index.php/jp/article/download/7865/3891

Samatowa, Usman. (2016). Pembelajaran IPA di Sekolah Dasar. Jakarta : Indeks

Santrock, John W. (2012). Life-Span Development. Jakarta : Erlangga

Sugiyono. (2015). Metode Penelitian Kuantifatif Kualitaitif R\&B. Bandung: Aflabeta

Syah. (2004). Psikologi Pendidikan dengan Pendekatan Baru. Bandung: PT Remaja Rosdakarya diakses dari: http://edutaka.blogspot.co.id/2015/03/modelpembelajaran-discoverylearning.html

Zuhdan K. Prasetyo. (2014). Pembelajaran Sains. Yogyakarta: Ombak. 